\title{
Isolation and purification of type A spermatogonia from the bovine testis
}

\author{
F. Izadyar ${ }^{1,2}$, G. T. Spierenberg 3 , L. B. Creemers ${ }^{1,2}$, \\ K. den Ouden ${ }^{1,2}$ and D. G. de Rooij ${ }^{1,2}$ \\ ${ }^{1}$ Department of Endocrinology, Faculty of Biology, University Medical Center Utrecht, \\ Utrecht, The Netherlands; and Departments of ${ }^{2}$ Cell Biology and ${ }^{3}$ Immunology, University \\ Medical Center Utrecht, Utrecht, The Netherlands
}

\begin{abstract}
The aim of this study was to isolate and purify bovine type A spermatogonia. Testes from 5-7-month-old calves were used to isolate germ cells using a two-step enzymatic digestion. During the isolation and purification steps, the viability of cells was determined using live/dead staining. The identity of type A spermatogonia during isolation and purification was determined under a light microscope equipped with a Nomarski lens. Isolated cells were characterized further by using specific markers for type A spermatogonia, including Dolichos biflorus agglutinin (DBA) and c-kit. The cell suspension was transplanted into immunodeficient recipient mouse testes and the colonization was assessed 1-3 months after transplantation, to assess the stem cell population among the isolated cells. After isolation, a cell suspension was obtained containing about $25 \%$ type A spermatogonia, which was enriched further by differential plating and separation on a discontinuous Percoll gradient. Finally, fractions containing
\end{abstract}

65-87\% pure type A spermatogonia were obtained. Large and small type $A$ spermatogonia with different numbers and sizes of nucleoli were found. DBA stained both large and small type A spermatogonia and its application in fluorescence-activated cell sorting (FACS) resulted in comparable percentages of type A spermatogonia to those determined by morphological examination under a light microscope equipped with a Nomarski lens. Nearly all of the large type A spermatogonia showed strong c-kit immunoreactivity, indicating that these cells had undergone at least an initial differentiation step. In contrast, approximately half of the small type A spermatogonia were negative for c-kit, indicating the presence of the spermatogonial stem cells in this population. At 3 months after transplantation, groups of bovine type A spermatogonia were found in most tubule cross-sections of the recipient mouse testes, showing the presence of spermatogonial stem cells among the isolated cells.

\section{Introduction}

Spermatogenesis is a complex, highly organized process that originates from stem cell spermatogonia. In nonprimate mammals, the $A_{s}$ (A single) spermatogonia are considered to be the stem cells of spermatogenesis (Huckins, 1971; Oakberg, 1971; de Rooij, 1973). Upon division of the $A_{s}$ spermatogonia, the daughter cells either migrate away from each other and become two new stem cells, or stay together through an intercellular bridge and become A-paired $\left(A_{p r}\right)$ spermatogonia. The $A_{p r}$ spermatogonia develop further into chains of four, eight or 16 A-aligned $\left(A_{a l}\right)$ spermatogonia. The $A_{a l}$ spermatogonia differentiate into A1 spermatogonia and after six mitotic divisions result in A2, A3, A4 and, finally, B spermatogonia, which give rise to spermatocytes at the last mitotic division. Irrespective of species-specific differences, in the bovine testis, a comparable classification with another terminology has been reported (Wrobel et al., 1995a). In this species,

Email: fizadyar@lab.azu.nl spermatogonial precursor cells have been divided into basal stem cells (BSC), aggregated spermatogonial precursor cells (ASPC) and committed spermatogonial precursor cells (CSPC), which, according to this classification, represent $A_{s}-A_{p r}$ spermatogonia, $A_{a l}$ spermatogonia and $A_{1}-A_{4}$ differentiating spermatogonia, respectively. Hence, in bulls, $A_{p r}$ spermatogonia are also thought to have stem cell properties (Wrobel, et al., 1995a).

As there are relatively few stem cells that can be defined only by their function, the identification and isolation of these cells has been very difficult. To date, the most effective way to enrich germ cell populations for stem cells is to purify all forms of type A spermatogonia. In the adult mammalian testis, owing to the presence of multiple generations of germinal cells, purification of spermatogonia is more difficult than it is before puberty. Bellve et al. (1977) obtained a 90\% pure fraction of type A spermatogonia from immature mice. Similarly, highly purified spermatogonia have been obtained from immature rat (Morena et al., 1996) and pig (Dirami et al., 1999) testes. In addition, vitamin A-deficient animals can be used as a source of spermatogonia as, in these animals, spermatogenesis stops at a spermatogonial 
differentiation step (van Pelt et al., 1996). At present, with the exception of a single study in which a mixed germ cell population, including type A spermatogonia, was collected from bovine testes and used for transplantation (Dobrinski et al., 2000), no information is available on the isolation of pure bovine type A spermatogonia.

In studies on spermatogonial isolation and purification, the availability of markers that can conclusively establish the identity of the spermatogonia is essential. One such a marker is c-kit, the receptor for stem cell factor (SCF), which is expressed by some $A_{a}$ and by $A_{1}-A_{4}$, In and $B$ spermatogonia, but not by $A_{s}$ and $A_{p r}$ spermatogonia (SchransStassen et al., 1999). Therefore, application of c-kit for isolation of spermatogonia results in the selection of more differentiated spermatogonia than spermatogonial stem cells (Shinohara et al., 2000). In contrast, isolation of mouse spermatogonia on the basis of $\alpha-6$ and $\beta-1$ integrin resulted in an enriched population of spermatogonial stem cells (Shinohara and Brinster, 2000). In bulls, the lectin Dolichos biflorus agglutinin (DBA), which has a specific affinity for $\alpha$-D- $N$-acetyl-galactosamine, can be used as a specific marker for gonocytes and spermatogonia in the testis during the first 30 weeks after birth (Ertl and Wrobel, 1992). We have developed a procedure by which highly purified type A spermatogonia can be isolated from the testes of 5-monthold bull calves. The aim of the present study was to investigate the morphological and physiological characteristics of the purified type A spermatogonia and their stem cell potential.

\section{Materials and Methods}

\section{Collection of testes and histology}

Testes from 3-7-month-old calves were collected from an abattoir, placed on ice and transferred to the laboratory within $2 \mathrm{~h}$, to study the development of spermatogenic cells during the prepubertal period. Approximately $20 \mathrm{~g}$ of testicular tissue was used for each cell isolation procedure and a sample was taken for histological examination. Testicular samples were fixed in Bouin's solution and embedded in glycol methacrylate Technovit 7100 (Kulzerand Co., $\mathrm{GmbH}$, Wehrheim). Sections of $5 \mu \mathrm{m}$ were cut, stained with periodic acid-Schiff and Gill's haematoxylin and evaluated under a light microscope.

\section{Cell isolation, purification and identification}

After decapsulation, the testes were minced into small pieces and suspended in minimum essential medium (MEM; Gibco Life technology, Paisley) supplemented with 14 mol $\mathrm{NaHCO}_{3} \mathrm{I}^{-1}, 4$ mol L-glutamine ${ }^{-1}$ (both from Sigma, St Louis, MO), single-strength non-essential amino acids, 100 iu $\mathrm{ml}^{-1}-100 \mu \mathrm{g} \mathrm{ml} \mathrm{m}^{-1}$ penicillin-streptomycin, $40 \mu \mathrm{g}$ gentamycin $\mathrm{ml}^{-1}$ and $15 \mathrm{~mol}$ Hepes $\mathrm{I}^{-1}$ (all from Gibco) (subsequently referred to as MEM). Seminiferous epithelial cells were dispersed with enzyme and separated using the method of van Pelt et al. (1996) with minor modifications. In brief, minced testis pieces were suspended in MEM containing $1 \mathrm{mg}$ collagenase $\mathrm{ml}^{-1}$ and $1 \mathrm{mg}$ trypsin $\mathrm{ml}^{-1}$ (both from Worthington, Freehold, NJ), $1 \mathrm{mg}$ hyaluronidase type $\mathrm{II} \mathrm{ml} \mathrm{m}^{-1}$ (Sigma) and $5 \mu \mathrm{g}$ DNAse I ml-1 (Boehringer, Mannheim) and incubated at $32^{\circ} \mathrm{C}$ for $60 \mathrm{~min}$ in a shaking waterbath operated at 140 cycles $\mathrm{min}^{-1}$. After three washes in MEM medium and removal of most of the interstitial cells, seminiferous cord fragments were incubated in MEM containing collagenase, hyaluronidase and DNAse for $45 \mathrm{~min}$ as described above. Cells were separated from the remaining tubule fragments by centrifugation at $30 \mathrm{~g}$ for $2 \mathrm{~min}$. After filtration through 77 and $55 \mu \mathrm{m}$ nylon filters, the cells were pelleted and subjected to differential plating to eliminate the somatic cells (myoid and Sertoli cells). The pooled cells were incubated overnight in MEM containing $10 \%$ FCS (Gibco) at $37^{\circ} \mathrm{C}$. After removal of Sertoli and myoid cells, spermatogonia, which remained in suspension, were collected and loaded onto a discontinuous Percoll density gradient for further purification (van Pelt et al., 1996). Fractions containing > 50\% type A spermatogonia were washed, counted and used. The purity of the cell suspension at the various steps was determined using Nomarski interference microscopy.

\section{Viability assays}

The viability of the cells during isolation and purification steps was determined using a live-dead kit (Molecular Probes, Eugene, OR). Viability was assessed by determining the number of calcein-AM-positive cells $\left(1 \mu \mathrm{mol} \mathrm{I}^{-1}\right.$ in MEM) and ethidium homodimer-positive cells $\left(1 \mu \mathrm{mol} \mathrm{I}^{-1}\right.$ in MEM) after $10 \mathrm{~min}$ of incubation at $37^{\circ} \mathrm{C}$. Binding of calcein-AM to the enzyme esterase, which is present in the cytoplasm of living cells only, produces a green colour. Ethidium homodimer passes through the plasma membrane of dead cells only, binding to the nucleus and producing a red colour.

\section{$D B A$ staining and FACS analysis}

Approximately $2 \times 10^{6}$ fixed cells were washed twice in PBS containing $5 \mathrm{mg} \mathrm{BSA} \mathrm{ml}^{-1}$ (PBS-BSA) to eliminate the fixative. After centrifugation at $2000 \mathrm{~g}$ for $5 \mathrm{~min}$, the pellet was resuspended (approximately $1 \times 10^{6}$ cells $\mathrm{ml}^{-1}$ ) in fluorescein isothiocyanate (FITC)-conjugated DBA at a concentration of $100 \mu \mathrm{g} \mathrm{ml}-1$ in PBS containing $10 \mathrm{mg}$ BSA $\mathrm{ml}^{-1}$ for $15 \mathrm{~min}$ at $37^{\circ} \mathrm{C}$. Cells were washed in PBS-BSA three times and finally the pellet was resuspended in $0.5 \mathrm{ml}$ PBS-BSA. Cells were first analysed under a fluorescence microscope (Nikon TE 200, Tokyo) to check the labelling. The fluorescence emission of the stained cells was measured on a FACScan flow cytometer interfaced to a Macintosh computer equipped with Cell Quest software (Becton \& Dickinson, San Jose, CA). The excitation sources consisted of an argon ion laser operated at $488 \mathrm{~nm}$. FITC fluorescence was monitored using a $530 \mathrm{~nm}$ band-pass filter and at least 10000 events were evaluated for each sample. 


\section{Immunohistochemcal localization of DBA and c-kit}

In addition to evaluation under a light microscope, type A spermatogonia were identified using DBA immunohistochemistry as described by Ertl and Wrobel (1992). Testicular sections fixed in Bouin's solution and embedded in paraffin wax, and isolated cells on glass chamber slides (Nunc, Life Technologies, Roskilde), also fixed in Bouin's solution and preserved in $70 \%$ ethanol, were used for immunohistochemistry. In brief, after removal of paraffin wax (for tissue sections only) and rehydration, sections were treated with $3 \%(\mathrm{v} / \mathrm{v}) \mathrm{H}_{2} \mathrm{O}_{2}$ (Merck, Darmstadt) for $10 \mathrm{~min}$ to inhibit endogenous peroxidase and were subsequently rinsed in PBS. Incubation in PBS containing $50 \mathrm{mg} \mathrm{BSA} \mathrm{ml} \mathrm{m}^{-1}$ for $15 \mathrm{~min}$ before lectin incubation was advantageous to block non-specific adhesion sites. The sections were then incubated in DBA conjugated with horseradish peroxidase (DBA-HRP; E. Y. Laboratories, San Mateo, CA) at 1:100 in PBS and $1 \%(\mathrm{w} / \mathrm{v})$ BSA for $1 \mathrm{~h}$ at $37^{\circ} \mathrm{C}$ in a moist chamber. After incubation with lectin, the sections were rinsed three times in PBS. Staining of the DBA-HRP was performed by treating the sections for 5-15 min with PBS containing $25 \mathrm{mg}$ 3,3'-diaminobenzidine tetrahydrochloride (DAB) (Sigma), $1 \mathrm{ml}$ nickel ammonium sulphate solution $\left(10 \mathrm{mg} \mathrm{ml}^{-1}\right), 1.25 \mathrm{ml}$ cobalt chloride solution ( $10 \mathrm{mg} \mathrm{ml}^{-1}$ ) and $17 \mu \mathrm{l}$ of $35 \%(\mathrm{v} / \mathrm{v}) \mathrm{H}_{2} \mathrm{O}_{2}$ per $50 \mathrm{ml}$. The slides were rinsed thoroughly in distilled water and, if necessary, counterstained with haematoxylin. The sections were dehydrated in graded alcohol, cleared in xylol and mounted with Pertex (Cell Path; Compulink, Bedford). Negative control sections were incubated in $1 \%$ BSA in PBS without lectin.

The differentiation stage of the type A spermatogonia was studied using c-kit immunolabelling. Testicular sections fixed in Bouin's solution and embedded in paraffin wax, and isolated cells also fixed in Bouin's solution and preserved in $70 \%$ ethanol, were used. The slides were washed in PBS for $10 \mathrm{~min}$, treated with $3 \%(\mathrm{v} / \mathrm{v}) \mathrm{H}_{2} \mathrm{O}_{2}$ for 10 min to inhibit endogenous peroxidase and rinsed in PBS. The slides were then incubated in the blocking solution containing 5\% normal goat serum (Vector, Burlingame, CA) with $10 \mathrm{mg}$ BSA ml-1 in PBS for $1 \mathrm{~h}$. All incubations were performed in a moist chamber at room temperature. After blocking, the slides were rinsed in acetylated BSA (BSA-c) $\left(0.5 \mathrm{mg} \mathrm{ml}^{-1}\right)$ in PBS (PBS-BSA-C) and incubated overnight with polyclonal rabbit anti-c-kit (C-19) antibody (1:100) diluted in PBS-BSA-C. After three rinses in PBS-BSA-C, the slides were incubated for $1 \mathrm{~h}$ with biotinylated goat anti-rabbit antibody (1:100) diluted in PBS-BSA-C. After rinsing in PBS, the slides were incubated in avidin-biotin complex (ABC) for $60 \mathrm{~min}$. The slides were then rinsed in Tris buffer solution (TBS) (0.05 mol Tris $\mathrm{I}^{-1}$ (Merck, Amsterdam) and $0.85 \mathrm{~mol} \mathrm{NaCl}$ $\left.\mathrm{I}^{-1}\right)$ containing $0.1 \%(\mathrm{v} / \mathrm{v})$ Tween-20 (Merck), and were incubated for 15-30 min in TBS containing $25 \mathrm{mg}$ DAB and $15 \mu \mathrm{l}$ of $3.5 \%(\mathrm{v} / \mathrm{v}) \mathrm{H}_{2} \mathrm{O}_{2}$. After rinsing thoroughly in water, the sections were studied under a Nikon inverted light microscope as described earlier.

\section{Preparation of donor cells and recipient testes, and transplantation}

After isolation and purification, the cells were resuspended in MEM-BSA-DNAse at a concentration of $20 \times 10^{6}$ cells $\mathrm{ml}^{-1}$ and kept on ice until transplantation. Adult NMRI mice HsdCpb (nu/nu; Harlan, Horst) were used as recipients. NMRI mice lack $\mathrm{T}$ cells and are immunodeficient; therefore, they were kept under specific pathogenfree conditions and food, water and bedding were autoclaved before use. The mice were housed in a $12 \mathrm{~h}$ light:12 h dark cycle at constant temperature and provided with food and water ad libitum. Recipient mice were given a fractionated X-ray dose of 1.5 and 12.0 Gy with an interval of $24 \mathrm{~h}$, to destroy endogenous spermatogenesis. This radiation dose is sufficient to block virtually all endogenous spermatogenesis and does not have any apparent harmful effect on supporting Sertoli cells (Creemers et al., in press). At 1 month after irradiation, the recipient mice were anaesthetized by i.p. administration of a mixture of fentanyl, fluanison and midazolam (10 mg kg-1; Roche, Mijdrecht). Testes were exposed through a mid-line abdominal incision, and donor cells (about $25 \mu \mathrm{l}$ ) were injected via a micropipette through the efferent ducts into the rete testis as described by Ogawa et al. (1997). The contralateral testis was used as the negative control. Testes were harvested at 1-3 months after transplantation, fixed in Bouin's solution and the colonization efficiency was assessed using DBA immunohistochemistry. The experimental protocol of this study followed the guidelines of the care and use of laboratory animals and was approved by the animal care and use committee of Utrecht University.

\section{Statistical analysis}

The results are presented as means \pm SEM and statistical analysis was performed by Student's $t$ test. Differences were considered significant when the $P$ value was $<0.05$.

\section{Results}

\section{Histology}

The presence of the various types of spermatogenic cells in the testes of prepubertal bulls of various ages (3-7 months) was studied (Figs 1 and 2). At 3 months of age, gonocytes were the only germ cells present. The gonocytes were large, localized mostly in the middle of the seminiferous tubules and occasionally at the basal membrane (Fig. 2a). However, by 5 months, most tubules contained type $A$ spermatogonia and gonocytes, and a few contained spermatocytes as the most advanced germ cells (Fig. 2b). At 6 months, the diameter of the seminiferous tubules increased and a lumen was observed for the first time. About $60 \%$ of the tubule cross-sections contained primary spermatocytes and $20 \%$ contained spermatids (Fig. 2c). At 7 months, the diameter of the seminiferous tubules had increased further 


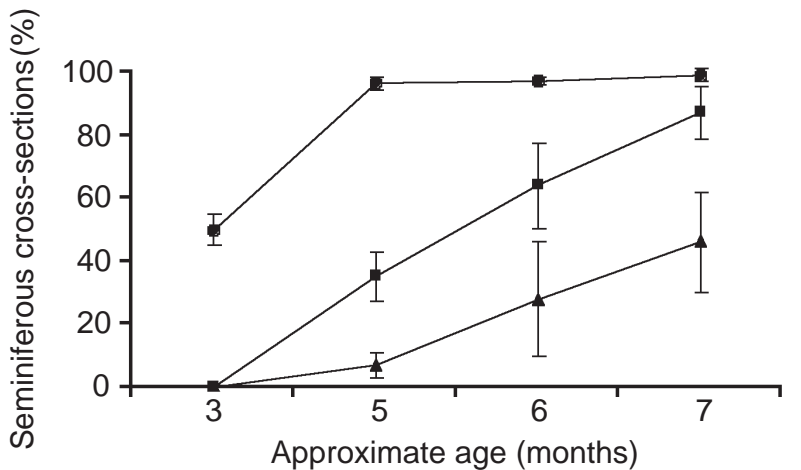

Fig. 1. Percentage of seminiferous tubules containing different types of germ cell in the testes of bull calves at different ages: spermatogonia and gonocytes; ( $\mathbf{\square})$ primary and secondary spermatocytes; $(\boldsymbol{\Lambda})$ round and elongated spermatids. The results represent pooled data obtained from 11 different animals (mean \pm SEM).

and a lumen was clearly visible. Elongated spermatids were the most advanced cells observed at 7 months (Fig. 2d).

\section{Cell isolation and purity}

After isolation, the cell suspension contained on average $25.5 \pm 2.8 \%$ type A spermatogonia. Differential plating and subsequent Percoll gradient separation significantly enhanced the purity of these cells to $45 \pm 3.1(P<0.01)$ and $73 \pm 2.9 \%(P<0.001)$, respectively. The viability of the cells after isolation was $>90 \%$, which diminished slightly after overnight culture and exposure to a Percoll gradient (Fig. 3a,b). Regardless of the age of the testes, most of the spermatogonia were found in fraction three of the Percoll gradient (Fig. 4), and the purity of the spermatogonial fraction was higher at 5 months than at 6 or 7 months (Fig. 5). When testes from 5-month-old calves were used, approximately $1 \times 10^{6}$ type $\mathrm{A}$ spermatogonia per gram of testes of a purity of about $75 \%$ could be obtained routinely.

\section{FACS analysis}

The purity of type A spermatogonia in the cell suspension was assessed using DBA-FITC and flow cytometry. Two subpopulations of DBA-FITC-positive cells were detected containing small and large cells, presumably small or large type A spermatogonia. The population of large cells was on average tenfold greater than the population of small cells (Fig. 6a,b). The purity of the type A spermatogonia, as assessed by morphological examination under a light microscope equipped with a Nomarski lens, was similar to that estimated by DBA flow cytometry.

\section{Identification of spermatogonia in the testis and after isolation}

In the seminiferous epithelium of 5-month-old calves, type A spermatogonia were round cells of various sizes with
Table 1. c-kit immunoreactivity of bovine type A spermatogonia in relation to the size of the spermatogonia

\begin{tabular}{llr}
\hline & \multicolumn{2}{c}{ c-kit immunoreactivity } \\
\cline { 2 - 3 } Size of type A spermatogonia & \multicolumn{1}{c}{ Positive } & \multicolumn{1}{c}{ Negative } \\
\hline Large & $93.4 \pm 3.6^{\mathrm{a}}$ & $6.6 \pm 3.7^{\mathrm{a}}$ \\
Small & $52.2 \pm 5.7^{\mathrm{b}}$ & $47.8 \pm 8.2^{\mathrm{b}}$ \\
\hline
\end{tabular}

Results are the pooled data from three independent experiments.

abWithin columns, values with different superscripts are significantly different $(P<0.05)$.

a spherical nucleus and one to three centrally located dense nucleoli of about 1-3 $\mu \mathrm{m}$ in diameter (Fig. 7a). Purified spermatogonia contained both large and small type A spermatogonia (Fig. 7b). Immunohistochemical staining for DBA showed that, in testes from 5-month-old calves, only type A spermatogonia were stained. DBA staining was localized mostly as a dense coloured area at the Golgi complex in the vicinity of the nucleus and was not detectable in the nucleus (Fig. 7c). In the testes of fivemonth-old calves, the intensity of staining for c-kit in type A spermatogonia varied and, in general, large type A spermatogonia had stronger c-kit immunoreactivity than did small type A spermatogonia (Fig. $7 \mathrm{~d}-\mathrm{f}$ ): $>90 \%$ of the large type A spermatogonia showed c-kit immunoreactivity, whereas about $50 \%$ of the small type A spermatogonia were negative for c-kit (Table 1).

\section{Evaluation of stem cell activity}

Isolated cells were transplanted into the testes of recipient immunodeficient mice to investigate the functionality of the spermatogonial stem cells among the isolated type A spermatogonia. Immediately after transplantation, bovine type A spermatogonia, as detected with DBA staining, were found in the seminiferous tubule lumen of the recipient mice (Fig. 8a). At 1 month after transplantation, a few bovine spermatogonia were found at the basal membrane of the tubules (Fig. 8b). At 3 months after transplantation, groups of DBA-positive cells, that is, bovine spermatogonia, were found in the tubule cross-sections of the recipient testes (Fig. 8c). At this time, bovine spermatogonia were found on average in $>60 \%$ of the tubule cross-sections. Bovine germ cells at advanced stages of development were not found in the mouse testis. DBApositive cells were not found in the contralateral control testis (Fig. 8d).

\section{Discussion}

This study demonstrates that highly purified type A spermatogonia can be obtained from the testes of 5-7month-old calves. In terms of the most appropriate age of calves from which to isolate type A spermatogonia, it appeared that at 5 months most of the tubule cross-sections 

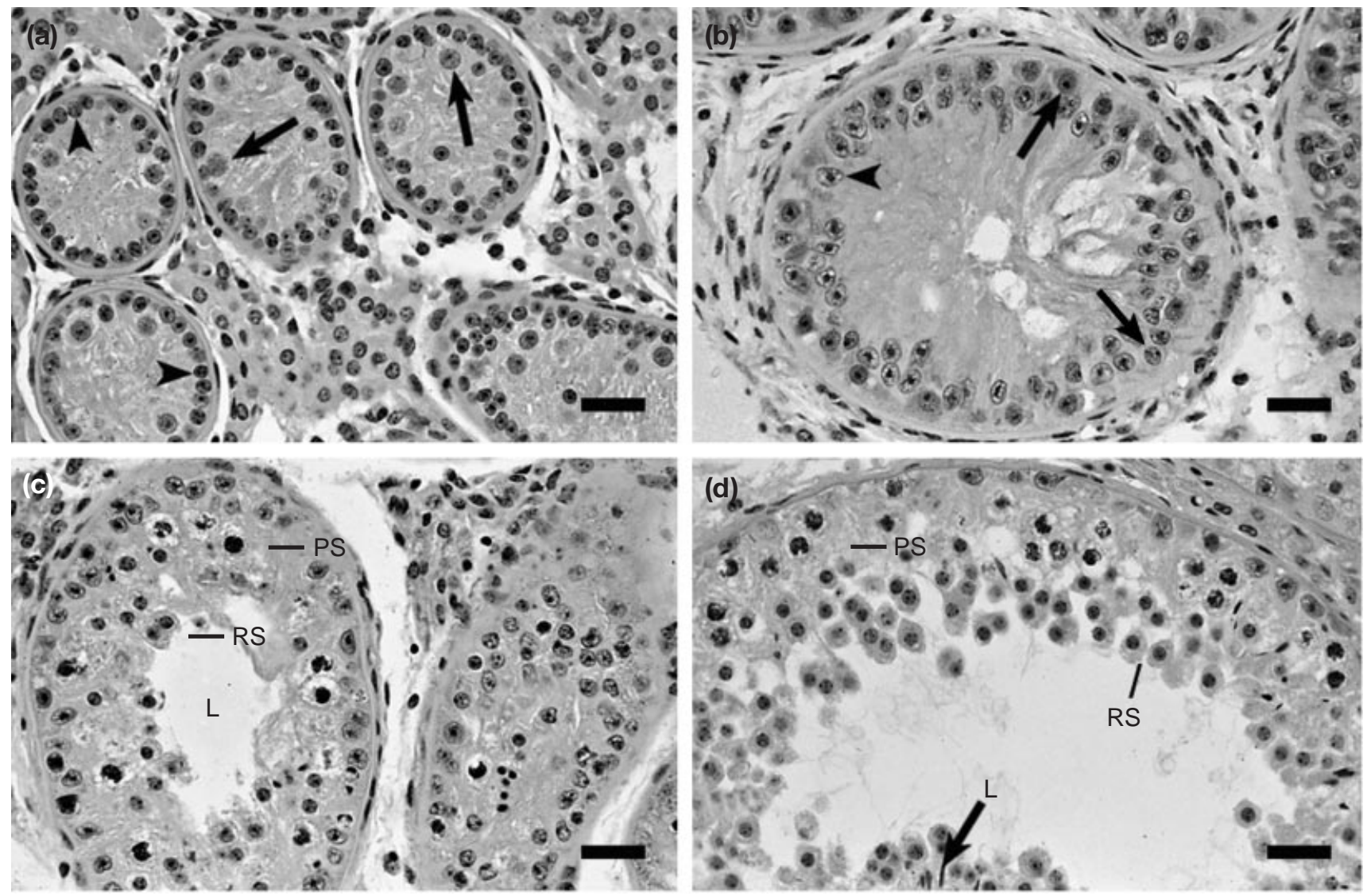

Fig. 2. Histological sections of testes from prepubertal calves aged 3-7 months. (a) At 3 months of age, only gonocytes (arrows) and preSertoli cells (arrowheads) were present. (b) By 5 months, spermatogonia (arrows) were the most frequent type of germ cell found at the basement membrane of the seminiferous tubules surrounded by Sertoli cells (arrowhead). Note the different sizes of spermatogonia. No central lumen was present. (c,d) At 6 and 7 months, the diameter of the seminiferous tubules had increased and a lumen (L) was present. In addition to spermatogonia, germ cells at more advanced stages of development were observed, including spermatocytes (PS), round spermatids (RS) and elongated spermatids (arrow). Scale bars represent $20 \mu \mathrm{m}$.

contained type A spermatogonia as the most advanced type of germ cell, and these testes proved to be the best source for isolation of this type of spermatogonia. Highly enriched populations of type A spermatogonia to a final purity of up to $75 \%$ could be isolated routinely. Cell recovery was about $1 \times 10^{6}$ type A spermatogonia per gram of testis and the viability of the isolated spermatogonia was always $>80 \%$. These results are comparable to those reported for the isolation of type A spermatogonia from prepubertal mice (Bellve et al., 1977), rats (Morena et al., 1996) and pigs (Dirami et al., 1999).

In the testicular sections of 5-month-old calves, different subpopulations of type A spermatogonia were observed: large cells with a large central nucleolus and small cells with one to three nucleoli. The isolated type A spermatogonia also contained populations of small and large spermatogonia. The difference in size of the spermatogonia may be related to the phase of the cell cycle (Lok et al., 1982). However, as the population of large spermatogonia was tenfold greater than the population of small spermatogonia, and as the G1 phase, during which the cells are small, occupies much more than $10 \%$ of the duration of the cell cycle, this explanation is unlikely. Therefore, the difference in size of the spermatogonia is more likely to be the result of the differentiation stage of these cells. Morphological studies of spermatogonia in the prepubertal bovine testis (Wrobel et al., 1995a, b; Wrobel, 2000), on the basis of electron microscopy and whole mount immunohistochemistry, showed that three groups of spermatogonia of different sizes can be distinguished: basal stem cells, aggregated spermatogonia and committed spermatogonia. Basal stem cells are small round cells containing one to three irregular nucleoli and are comparable to $A_{s}$ and $A_{p r}$ spermatogonia. Aggregated spermatogonia are of different sizes from small to large, contain one to two nucleoli and resemble $A_{a l}$ spermatogonia. Committed spermatogonia are the largest type of spermatogonia found in the testis, have a large centrally located nucleolus and are com- 
(a)
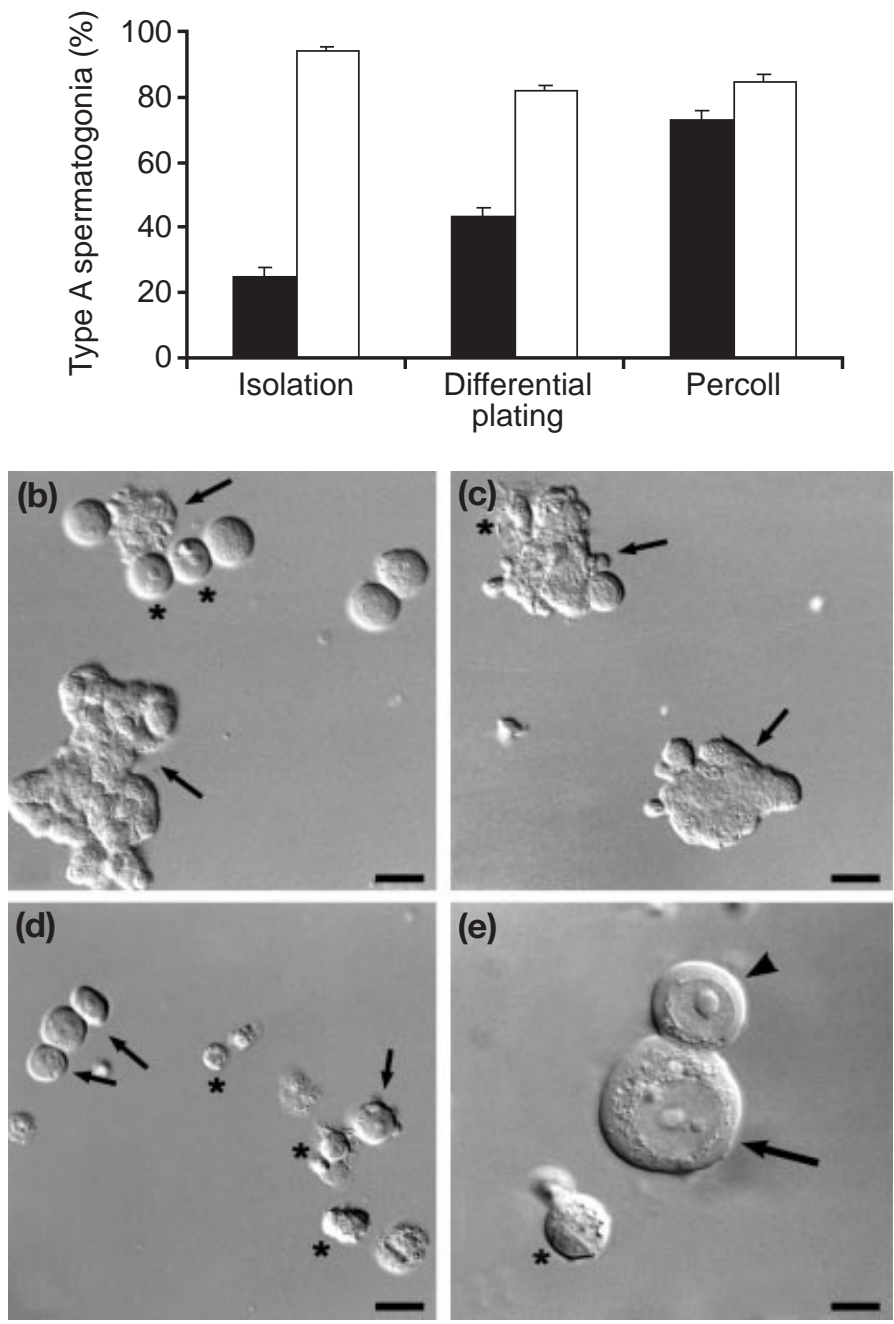

Fig. 3 (a) Purity ( $\square$ ) and viability ( $\square$ ) of bovine type A spermatogonia at various stages of the cell isolation and purification procedure. The results represent pooled data obtained from 15 different experiments and are presented as mean \pm SEM. (b-e) Purity of type A spermatogonia after isolation and during purification stages, as assessed by Nomarski interference microscopy. (b) Note the presence of cell clumps (arrows) accompanying the isolated type A spermatogonia (asterisks). (c) Two large cell clumps removed from the cell suspension after purification (arrows). Note the morphology of the pre-tubular cell in one of the clumps (asterisk). (d) Morphology of the contaminating somatic cells (asterisks) and cell debris accompanying the type A spermatogonia (arrows). (e) Large (arrow) and small (arrowhead) spermatogonia and a testicular somatic cell (asterisk). Scale bars represent (b-d) $12.5 \mu \mathrm{m}$ and (e) $5 \mu \mathrm{m}$.

parable to $A_{1}-A_{4}$ differentiating spermatogonia. Therefore, the large spermatogonia observed in the present study probably consisted of differentiating $\left(\mathrm{A}_{1}-\mathrm{A}_{4}\right)$ subpopulations of spermatogonia. In addition, in the testes of 5month-old calves, a few seminiferous tubules contained gonocytes. Although gonocytes are large cells and after isolation might be mistaken for large type A spermatogonia, there are very few of these cells and the size and number of nucleoli make them distinguishable from the large type A spermatogonia. 


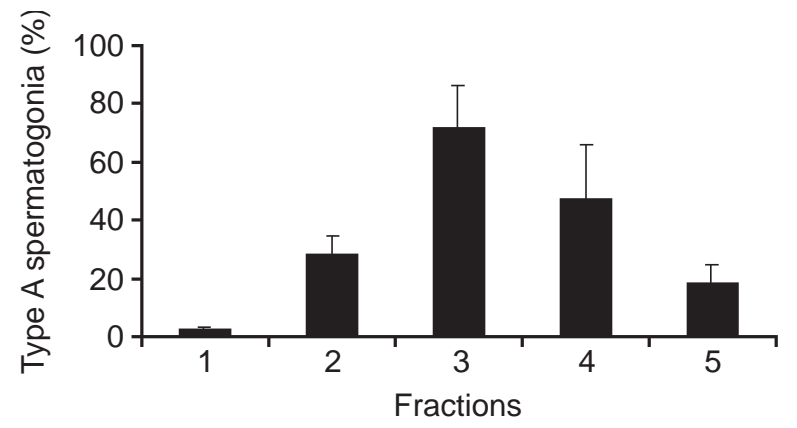

Fig. 4. Relative numbers of bovine type A spermatogonia present in different fractions of the Percoll gradient. The results represent pooled data obtained from ten different experiments and are presented as mean \pm SEM.
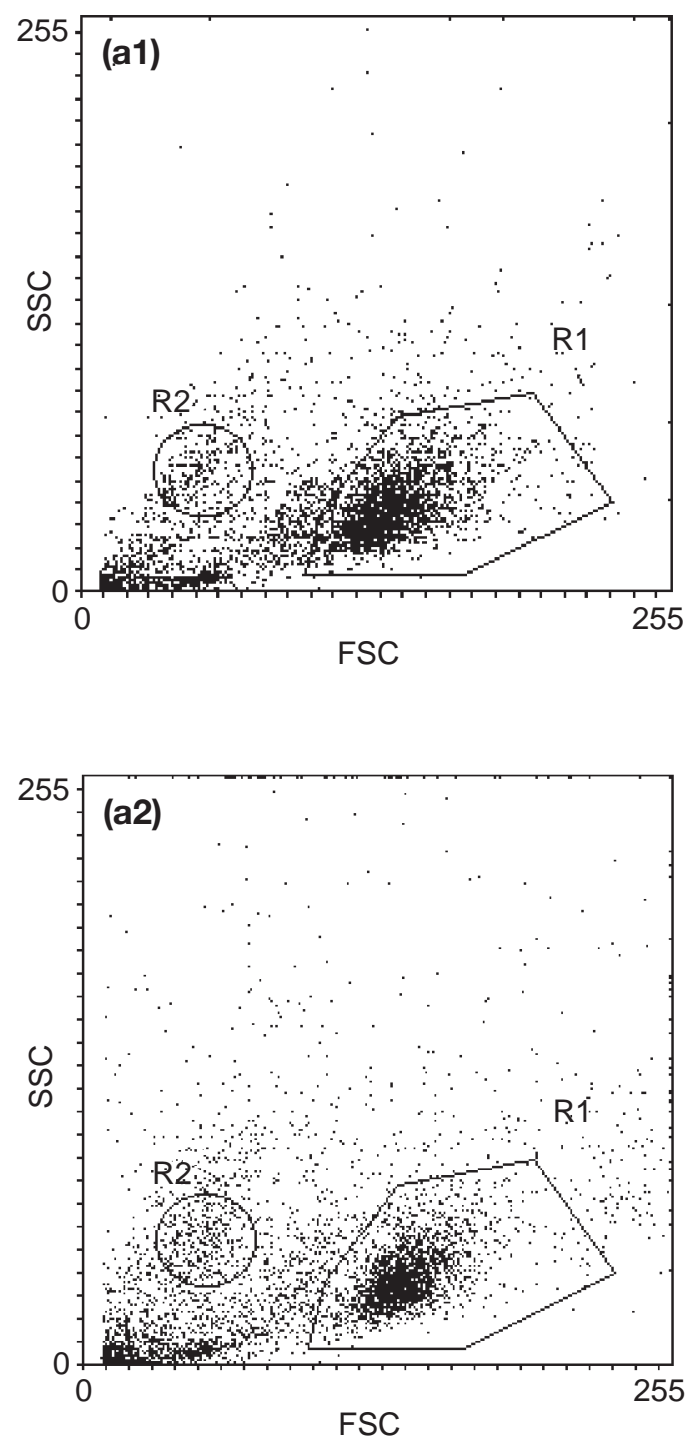

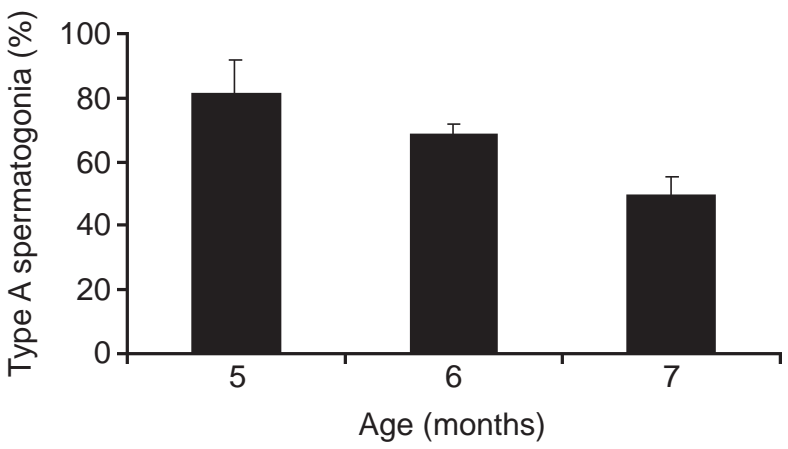

Fig. 5. Efficiency of the purification procedure for bovine type A spermatogonia from calves of various ages. The results represent pooled data obtained from 12 different experiments and are presented as mean \pm SEM.
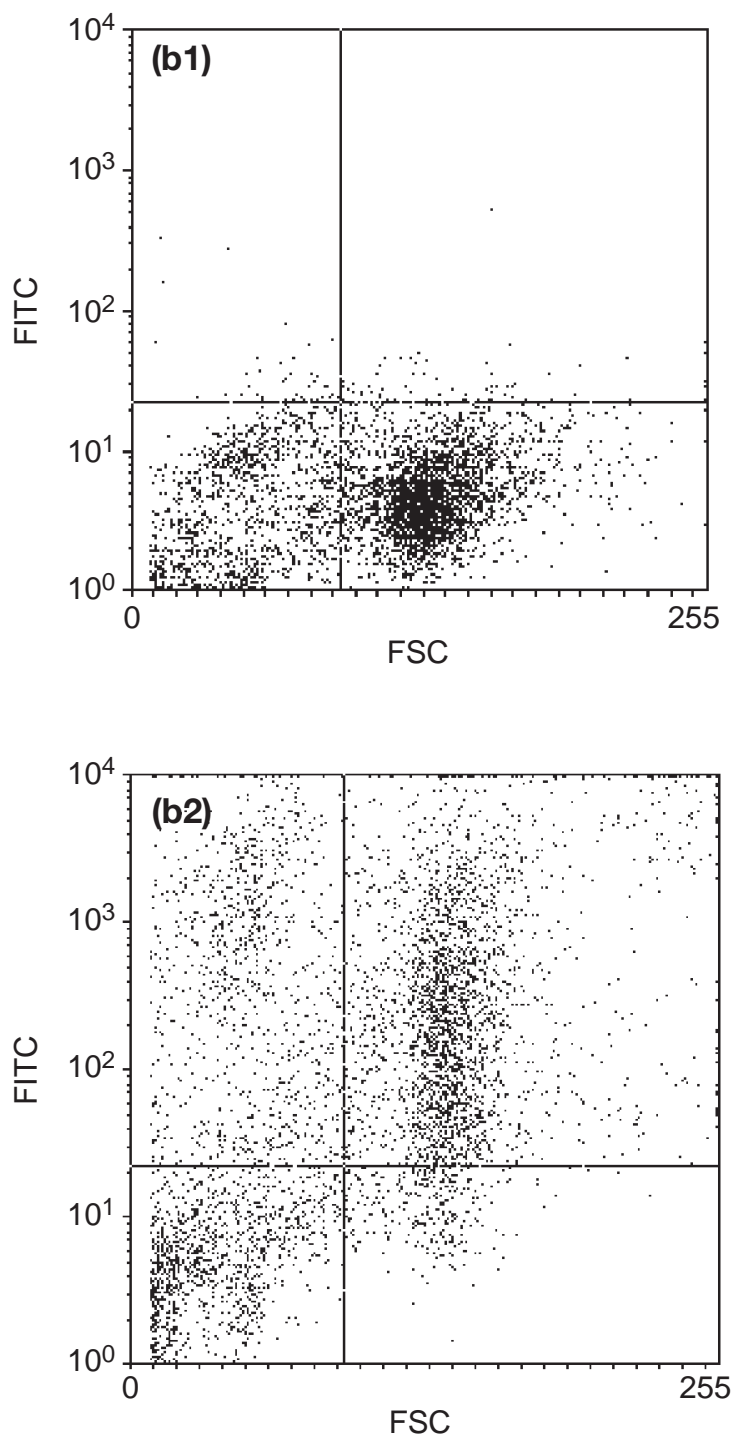

Fig. 6. Dolichos biflorus agglutinin (DBA) fluorescence distribution after staining of bovine spermatogonia with DBA-fluorescein isothiocyanate (FITC). Dot plot representation showing subpopulations of DBA-FITC-labelled cells according to their size or the fluorescence intensity. (a) Cell size measured by forward scatter (FSC) against side scatter (SSC); (b) fluorescence measured by forward scatter (FSC) against FITC. (1) Pure type A spermatogonia without DBA staining as the negative control; (2) the same cell population stained with DBA-FITC. R1: large cells; R2: small cells. This experiment consisted of three replicates. The result is a representative data set from an independent experiment. 

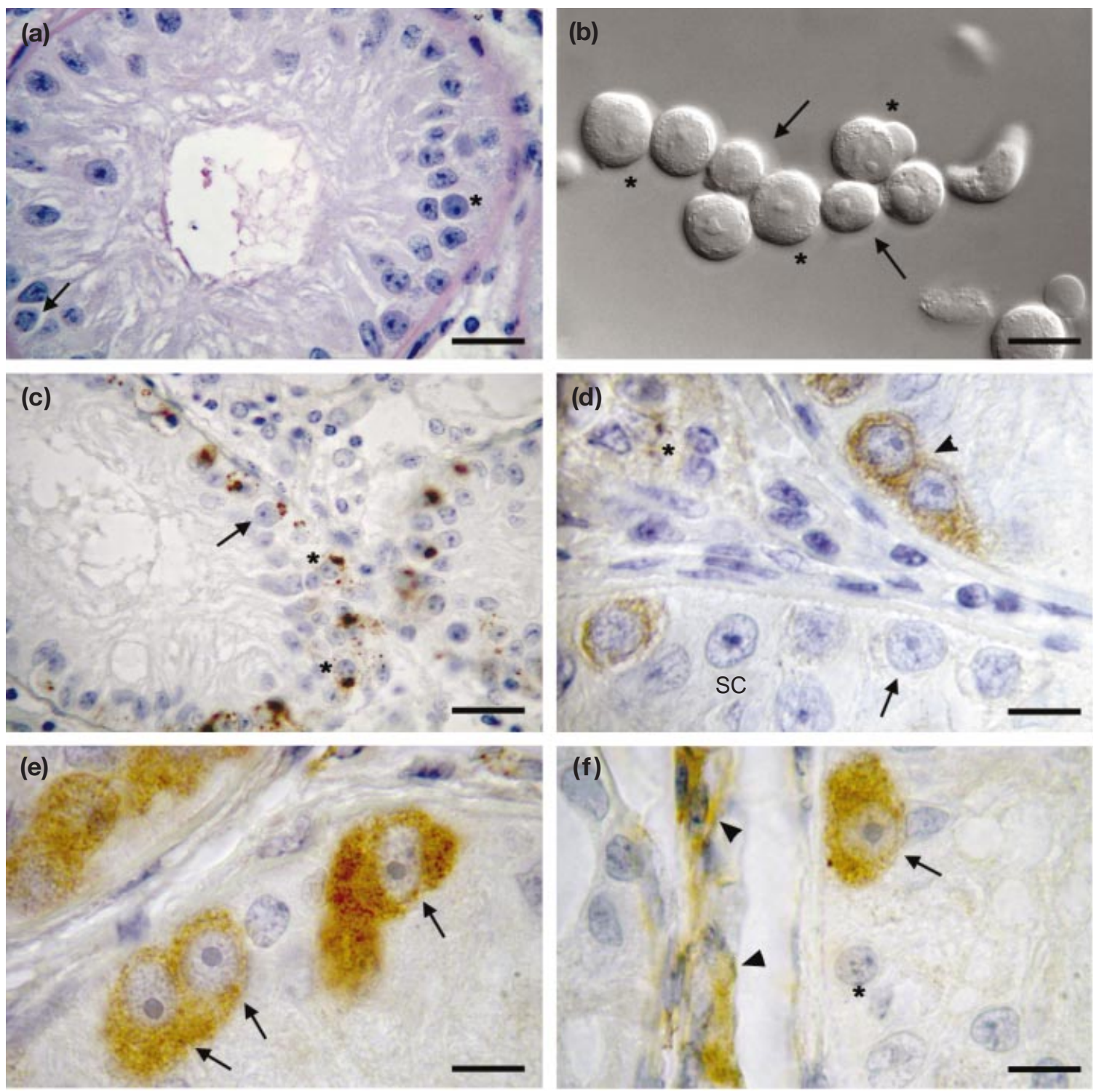

Fig. 7. Characterization of spermatogonia from the testes of 5-month-old calves before and after cell isolation. (a) Tubular cross-section of the testis after periodic acid-Schiff-haematoxylin staining. Although it is difficult to compare the size of the cells in testicular sections, both large (asterisk) and small (arrow) type A spermatogonia were observed. (b) Enriched type A spermatogonia obtained from prepubertal bulls shortly after isolation and purification; both large (asterisks) and small (arrows) type A spermatogonia were present. (c) Immunohistochemical localization of the marker for spermatogonia Dolichos biflorus agglutinin (DBA). Note that type A spermatogonia exclusively are stained in testes from 5-month-old calves. Both large (arrow) and small (asterisks) type A spermatogonia were stained. Note the intense staining in the cytoplasm, especially in the vicinity of the nucleus. (d-f) Immunohistochemical localization of the differentiation marker c-kit. (d) Note the differences in the intensity of c-kit staining among spermatogonia. Two connected spermatogonia show strong c-kit immunoreactivity (arrowhead); other spermatogonia are negative for c-kit (arrow). c-kit staining was not found in the surrounding Sertoli cells (SC). However, interstitial cells (asterisk) were positively stained for c-kit. (e) Strong c-kit immunoreactivity was observed among the large type A spermatogonia (arrows). (f) A large type A spermatogonia (arrow) showing strong immunoreactivity for c-kit and a small type A spermatogonia (asterisk) with a negative immunoreaction for c-kit. Note that the interstitial cells (arrowheads) were positively stained for c-kit. Scale bars represent (a,c) $40 \mu \mathrm{m}$ and (b,d-f) $15 \mu \mathrm{m}$. 

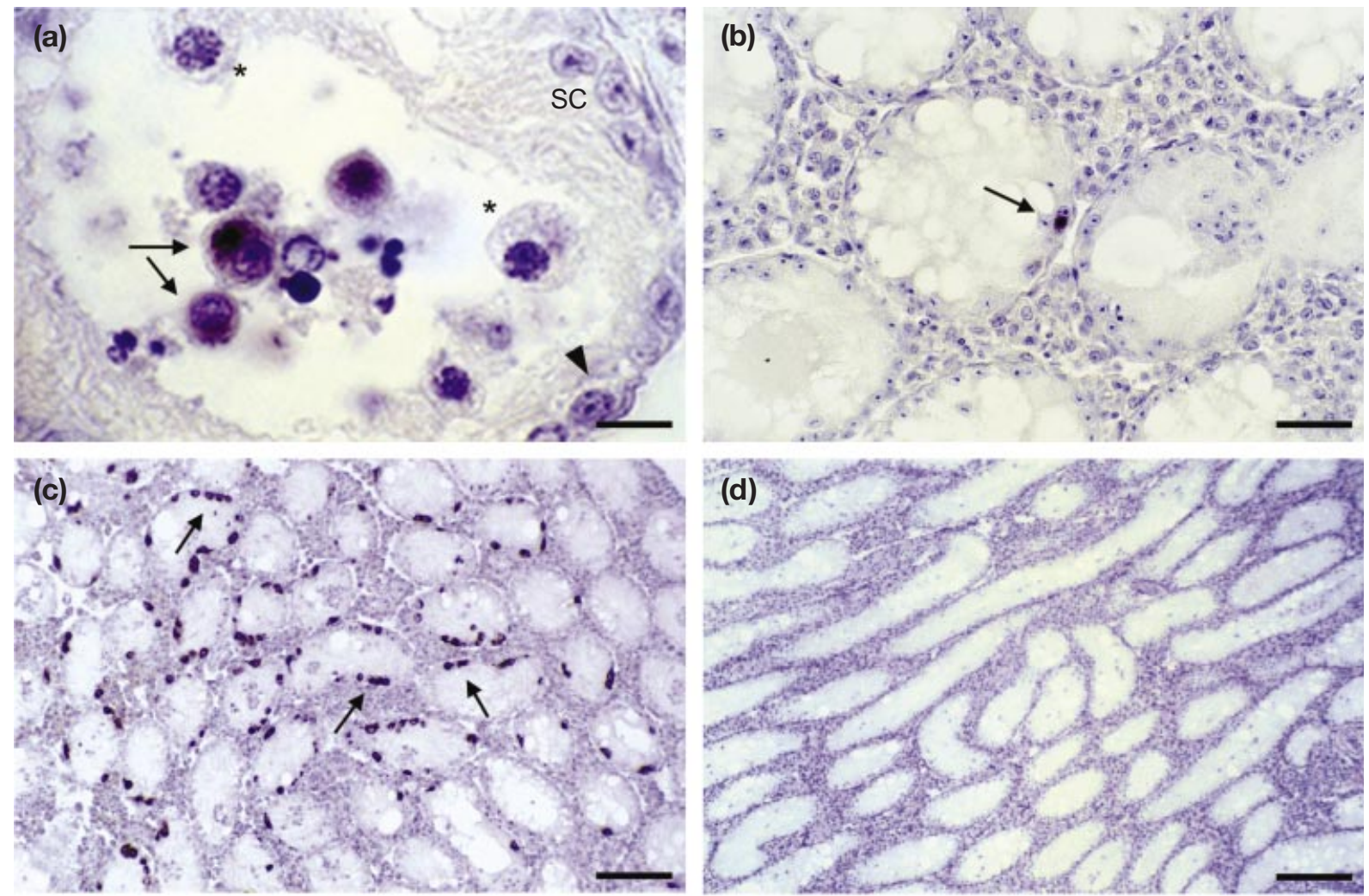

Fig. 8. Identification of bovine type A spermatogonia after transplantation into the testes of recipient mice. (a) Immediately after transplantation, bovine spermatogonia (arrows), as detected by Dolichos biflorus agglutinin (DBA), were found in the lumen of the tubule cross-section of the recipient testis. DBA staining was not found in mouse spermatogonia (arrowhead) or in the Sertoli cells (SC) and spermatocytes (asterisks) present in the testis. (b) At 1 month after transplantation, individual DBApositive cells, that is, bovine spermatogonia (arrow), were found at the basal membrane of the recipient testes. (c) At 3 months after transplantation, DBA-positive cells (arrows) were observed in most of the tubule cross-sections. (d) DBA-positive cells were not found in the contralateral control testis. Scale bars represent (a) $12.5 \mu \mathrm{m}$ and (b-d) $125 \mu \mathrm{m}$.

Nearly all large type A spermatogonia in the testes of 5-month-old calves were c-kit-positive. In contrast, the proportion of c-kit-positive cells in the population of small spermatogonia was much lower. This finding confirms the classification of Wrobel et al. (1995a) that smaller spermatogonia are less differentiated than larger spermatogonia. The presence of the c-kit receptor in spermatogonial stem cells has been a matter of debate for many years. In the mouse testis, $A_{s}$ and $A_{p r}$ spermatogonia are c-kit-negative, whereas late $A_{a l}$ to $B$ spermatogonia are c-kit positive (Schrans-Stassen et al., 1999). In addition, transplantation studies showed that c-kit-negative type A spermatogonia have a greater colonization efficiency than do the c-kit-positive cells (Shinohara et al., 2000), indicating that the c-kit-negative spermatogonia are testicular stem cells.

The presence of stem cells among the isolated type A spermatogonia was studied by transplanting the isolated cells into the testes of recipient mice. Extensive repopulation of the recipient testes by bovine spermatogonia indicated the presence of a considerable number of spermatogonial stem cells among the purified type A spermatogonia. In the mouse testis, approximately $1.3 \%$ of the type A spermatogonia are considered to be stem cells (Tegelenbosch and de Rooij, 1993). Assuming that there is the same ratio in the bovine testis, the expected yield of spermatogonial stem cells per gram of testis would be expected to be about $1 \times 10^{4}$.

In conclusion, a procedure was developed by which highly purified type A spermatogonia can be obtained from the testes of 5-month-old calves. Large, pure populations of type A spermatogonia, including spermatogonial stem cells, can be used to study gene expression in these cells and to develop a culture method for spermatogonia.

This work was supported by grants from the Netherlands Technology Foundation (STW), co-ordinated by the Council of Earth and Life Sciences (ALW), and the National Institutes of Health (NIH). The authors would like to thank RVV Amsterdam slaughterhouse for supplying the testes. R. Scriwanek and M. van Peski are acknowledged for their gracious help with photography. 


\section{References}

Bellve AR, Cavicchia JC, Millette CF, O'Brien DA, Bhatnagar YM and Dym M (1977) Spermatogenic cells of the prepubertal mouse. Isolation and morphological characterization Journal of Cell Biology 74 68-85

Creemers LB, Meng X, den Ouden K, van Pelt AMM, Izadyar F, Santoro M, Sariola $\mathbf{H}$ and de Rooij D Transplantation of germ cells from GDNFoverexpressing mice to host testes depleted from endogenous spermatogenesis by fractionated irradiation Biology of Reproduction (in press)

de Rooij DG (1973) Spermatogonial stem cell renewal in the mouse. I. Normal situation Cell and Tissue Kinetics 6 281-287

Dirami G, Ravindranath N, Pursel V and Dym M (1999) Effects of stem cell factor and granulocyte macrophage-colony stimulating factor on survival of porcine type A spermatogonia cultured in KSOM Biology of Reproduction 61 225-230

Dobrinski I, Arvarbock MR and Brinster RL (2000) Germ cell transplantation from large domestic animals into mouse testes Molecular Reproduction and Development 57 270-279

Ertl C and Wrobel KH (1992) Distribution of sugar residues in the bovine testis during postnatal ontogenesis demonstrated with lectinhorseradish peroxidase conjugates Histochemistry 97 161-171

Huckins C (1971) The spermatogonial stem cell population in adult rats. I. Their morphology, proliferation and maturation Anatomical Record 169 533-557

Lok D, Weenk D and de Rooij DG (1982) Morphology, proliferation and differentiation of undifferentiated spermatogonia in the Chinese hamster and the ram Anatomical Record 203 83-99

Morena AR, Boitani C, Pesce M, De Felici M and Stefanini M (1996) Isolation of highly purified type A spermatogonia from prepubertal rat testis Journal of Andrology 17 708-717

Oakberg EF (1971) Spermatogonial stem-cell renewal in the mouse Anatomical Record 169 515-531
Ogawa T, Arechaga JM, Avarbock MR and Brinster RL (1997) Transplantation of testis germinal cells into mouse seminiferous tubules International Journal of Developmental Biology 41 111-122

Schrans-Stassen BHGJ, van de Kant HJG, de Rooij DG and van Pelt AMM (1999) Differential expression of c-kit in mouse undifferentiated and differentiating type A spermatogonia Endocrinology 140 5894-5900

Shinohara T and Brinster RL (2000) Enrichment and transplantation of spermatogonial stem cells International Journal of Andrology 23 89-91

Shinohara T, Orwing KE, Avarbock MR and Brinster RL (2000) Spermatogonial stem cell enrichment by multiparameter selection of mouse testis cells Proceedings National Academy of Sciences USA 97 8346-8351

Tegelenbosch RA and de Rooij DG (1993) A quantitative study of spermatogonial multiplication and stem cell renewal in the $\mathrm{C} 3 \mathrm{H} / 101 \mathrm{~F} 1$ hybrid mouse Mutation Research 290 193-200

van Pelt AMM, Morena AR, van Dissel-Emiliani FMF, Boitani C, Gaemers IC, de Rooij DG and Stefanini M (1996) Isolation of the synchronized A spermatogonia from adult vitamin A-deficient rat testes Biology of Reproduction 55 439-444

Wrobel KH (2000) Prespermatogenesis and spermatogoniogenesis in the bovine testis Anatomy and Embryology 202 209-222

Wrobel KH, Bickel D, Kujat R and Schimmel M (1995a) Evolution and ultrastructure of the bovine spermatogonia precursor cell line Cell and Tissue Research 281 249-259

Wrobel KH, Bickel D, Kujat R and Schimmel M (1995b) Configuration and distribution of bovine spermatogonia Cell and Tissue Research 279 277-289

Received 20 November 2001.

First decision 25 January 2002.

Revised manuscript received 22 February 2002.

Accepted 14 March 2002. 